\title{
High Affinity Immunoglobulin Epsilon Receptor Subunit Beta
}

National Cancer Institute

\section{Source}

National Cancer Institute. High Affinity Immunoglobulin Epsilon Receptor Subunit Beta. NCI Thesaurus. Code C101625.

High affinity immunog lobulin epsilon receptor subunit beta (244 aa, $27 \mathrm{kDa}$ ) is encoded by the human MS4A2 gene. This protein is involved in the response to allergens. 